\title{
EVALUATION OF THE EFFECT \\ OF ENVIRONMENTAL VARIABLES ON HEALTH CONDITION OF Quercus robur L. IN PARKS
}

\author{
OCENA WPŁYWU ZMIENNYCH ŚRODOWISKOWYCH \\ NA STAN ZDROWOTNY Quercus robur L. W PARKACH
}

\begin{abstract}
Investigations concerned the effect of different environmental variables on health condition of English oak (Quercus robur L.). It was shown that in the public parks in the city of Poznan the health condition of the analysed species is good. It was stated that health condition of this species in the Poznan parks is influenced by the distance from the immediate city centre, vicinity of traffic arteries and gas emissions from the combustion of fossil fuels by households neighbouring with the parks. Although results recorded in this study confirm literature data concerning the effect of environmental variables on health condition of English oak (Quercus robur L.), it was shown that certain environmental variables have a greater effect on health condition of the analysed species in Poznan.
\end{abstract}

Keywords: English oak (Quercus robur L.), health condition, Poznan, environmental variables, statistical models

The genus Quercus belongs to the family Fagaceae. Scientific sources mention 500 oak species, of which most are found in the northern hemisphere - in the temperate and subtropical zones and in mountains in the tropical zone. The three oak species found in Poland, including English oak (Quercus robur L.), belong to the subspecies Quercus, section Quercus [1].

Research indicated that English oak, as a thermophilic species, grows well even when the temperature of the rhizosphere is $35^{\circ} \mathrm{C}$ [2]. It results from a study by Thomas and Sporns that mature trees of this species growing in soil with an elevated nitrogen content and threatened with defoliation caused by insects are more susceptible to damage during very cold winters [3, 4]. It was also shown that trees of this species exhibit a marked response to soil drought [5] as well as sensitivity to excess water content in soil, particularly in the period of vegetative growth [6]. It was also stated that Quercus robur L. is a species highly resistant to the action of wind, thanks to which it is recommended for planting in

\footnotetext{
${ }^{1}$ Department of Landscape Architecture, Poznan Univeristy of Life Sciences, ul. J.H. Dąbrowskiego 159, 60-594 Poznan, Poland, phone +48 6184879 92, fax +48 618487959

*Corresponding author: ktzkrzyzaniak@gmail.com
} 
wind belts and an admixture of this species in the stand reduces the probability of great wind damage [7]. Sonesson pointed to the fact that oaks devoid of over $60 \%$ their assimilatory organ usually within several years, while specimens of this species damaged to a lesser degree survive and frequently regenerate [8]. However, Eichhorn and Paar indicated that single older oaks may die at a defoliation of as little as 20\% [9].

Bugala pointed to the currently slight importance of Quercus robur L. in urban and housing district plantings, which results from the very limited production of this species in nurseries and poor tolerance to transplantation at an older age. The same author also indicated insufficient utilisation of this species in park plantings - despite tolerance to drought and air pollution and high tolerance to soil conditions [10].

In comparison to trees of other species the degree of tolerance to nitrogen oxides in English oak is high [11]. According to Saha and others, toxic gases for English oak may be ordered in terms of their toxicity (from the least to the most toxic) as follows: $\mathrm{Cl}_{2}, \mathrm{SO}_{2}, \mathrm{NO}_{2}$ and $\mathrm{NH}_{3}$ [12]. Following the data reported by Karolewski English oak is a species very or relatively resistant to the action of $\mathrm{SO}_{2}$. The same author indicates that the described species is tolerant to the effect of oxidative gases $\left(\mathrm{O}_{3}, \mathrm{PAN}, \mathrm{NO}\right)$, acidic gases $\left(\mathrm{SO}_{2}\right)$ and basic gases $\left(\mathrm{NH}_{3}\right)$ and it is not very sensitive to the action of fluorine compounds and ions of toxic metals [13]. Also according to Kardel and others, species from the genus Quercus are not very sensitive to $\mathrm{SO}_{2}$ concentration in air, as they tolerate mean annual concentration of $0.17 \mathrm{mg} \mathrm{SO} / 2 \mathrm{~m}^{3}$ and mean concentration in the vegetation season of $0.12 \mathrm{mg} \mathrm{SO} / \mathrm{m}^{3}$ [14]. It was found that Quercus robur L. is more sensitive to acid rains than Turkey oak (Quercus cerris L.) or pubescent oak (Quercus pubescens Willd.), although leaf damage symptoms (necroses and chloroses) appear on leaves at pH below 3.5 [15]. Brischke and others stated that Quercus robur L. is a species of low tolerance to dusts containing cations of toxic metals $(\mathrm{Cd}, \mathrm{Cu}, \mathrm{Pb}, \mathrm{Zn})$ and it is more tolerant to these metals than Fagus sylvatica $\mathrm{L}$. and Fraxinus excelsior L. [16]. English oak is a species tolerant to emissions of $\mathrm{SO}_{2}$ and $\mathrm{HF}$ as well as coal dust and dusts containing ions of noxious metals. This species is also tolerant to dusts containing $\mathrm{Zn}, \mathrm{Pb}$ and $\mathrm{Fe}$ as well as coke dust. Thanks to the above this species is suitable for plantings in areas affected by emissions of dusts containing heavy metals $(\mathrm{Cu}$, $\mathrm{Zn}, \mathrm{Pb}$ and $\mathrm{Cd}$ ) and $\mathrm{SO}_{2}$ [17-19]. Mertens and others stated that Quercus robur L. tolerates even the most difficult urban conditions and behaves identically all urban localities distinguished by that authors [20]. However, Meyer and others observed that urban conditions in München are much better tolerated by trees from genera Fraxinus and Aesculus as well as by Populus nigra L. 'Italica' than by Quercus robur L. [21].

\section{Materials and methods}

Investigations were conducted in public parks in Poznan, in which the proportion of English oak (Quercus robur L.) in the stand exceeds 5\%. They are parks (numbering consistent with that in Fig. 1):

1. Park Tysiaclecia Panstwa Polskiego (Fig. 2) - the proportion of English oak in the park tree stand of $15.4 \%$.

2. Park between housing districts: Osiedle Czecha and Osiedle Rusa (Fig. 3) - the proportion of English oak in the park tree stand of 5.1\%.

3. Park im. Jana Pawla II (Fig. 4) - the proportion of English oak in the park tree stand of $15.4 \%$. 
4. Park Gorczynski (Fig. 5) - the proportion of English oak in the park tree stand of 7.0\%,

5. Park im. ks. Jozefa Jasinskiego (Fig. 6) - the proportion of English oak in the park tree stand of $10.7 \%$.

6. Park im. Gustawa Manitiusa (Fig. 7) - the proportion of English oak in the park tree stand of $21.0 \%$.

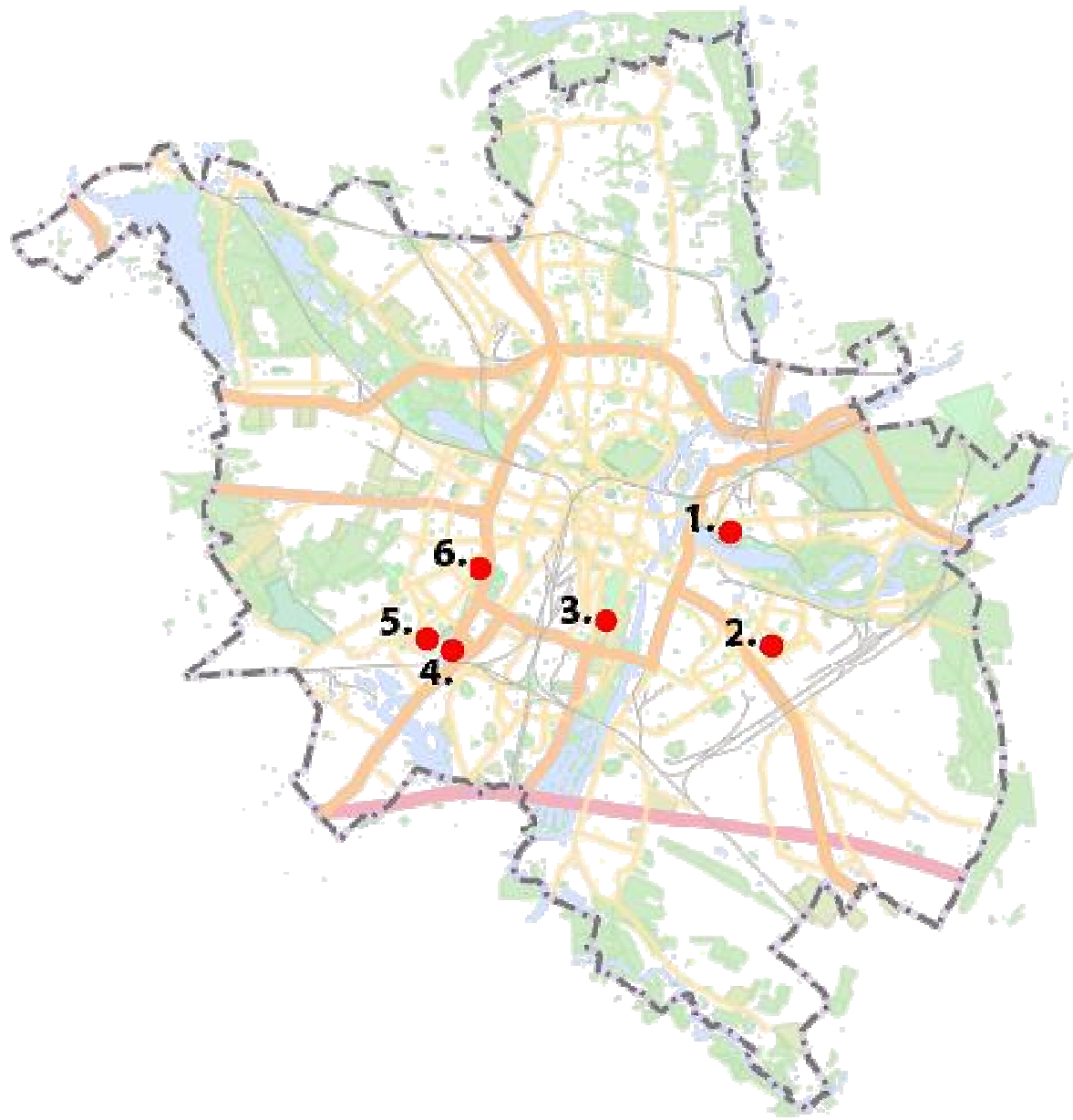

Fig. 1. A map of Poznan with marked locations of parks analysed in this study (source of map: http://www.poznan.pl/mim/public/ plan/plan.html; author: M. Krzyzaniak)

Two of the above mentioned objects are parks established in the area of former forts of the outer ring of Prussian fortifications from the second half of the 19th century (the park between Osiedle Czecha and Osiedle Rusa and Park im. ks. Jozefa Jasinskiego), while two others were created by a transformation of former evangelical cemeteries (Park Gorczynski and Park im. Gustawa Manitiusa). 


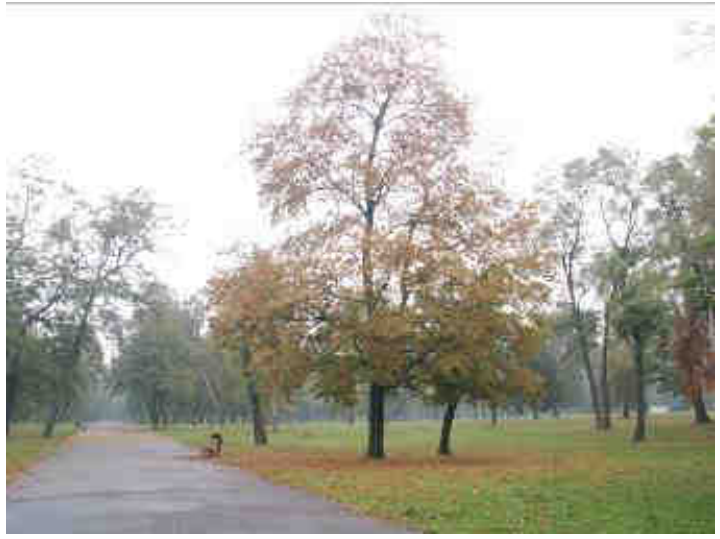

Fig. 2. Park Tysiaclecia Panstwa Polskiego

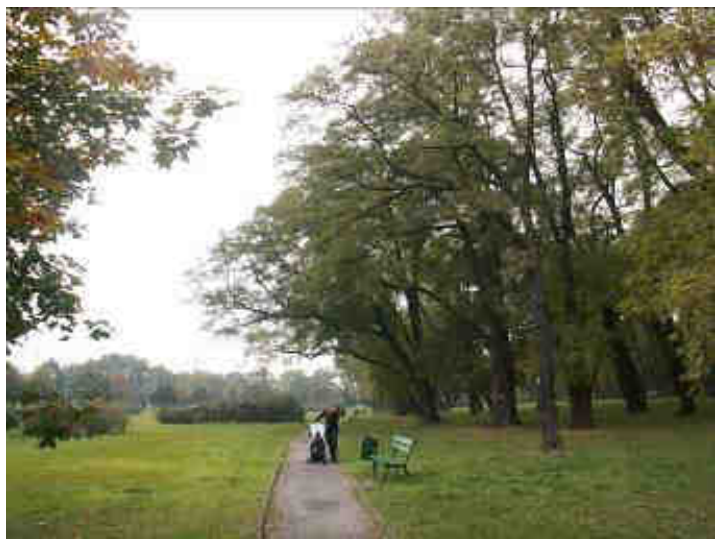

Fig. 3. Park between housing districts: Osiedle Czecha and Osiedle Rusa

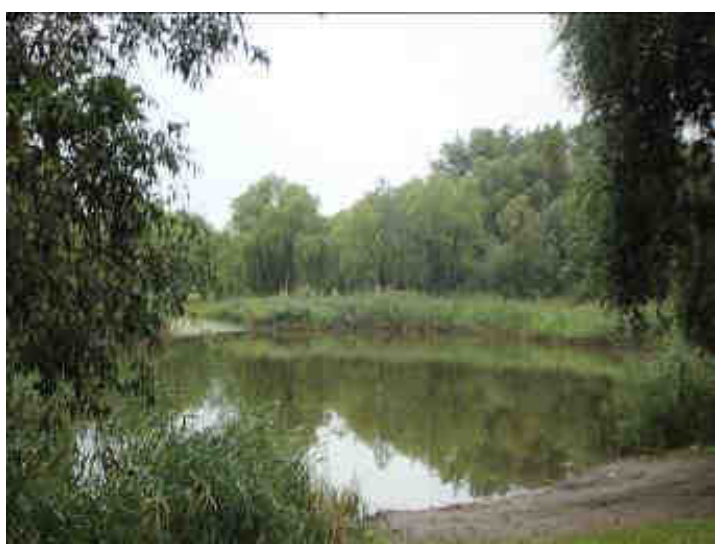

Fig. 4. Park im. Jana Pawla II 


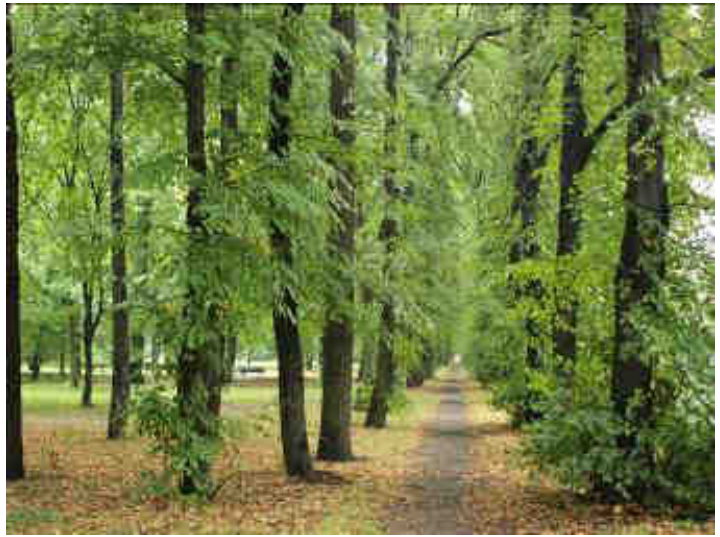

Fig. 5. Park Gorczynski

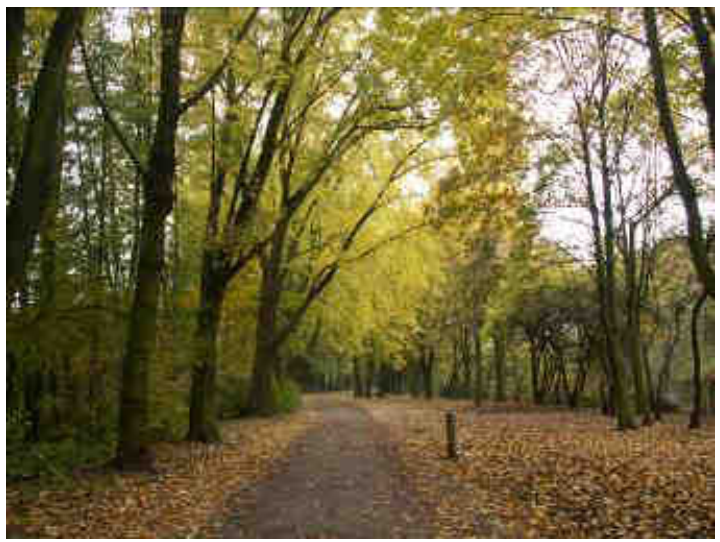

Fig. 6. Park im. ks. Jozefa Jasinskiego

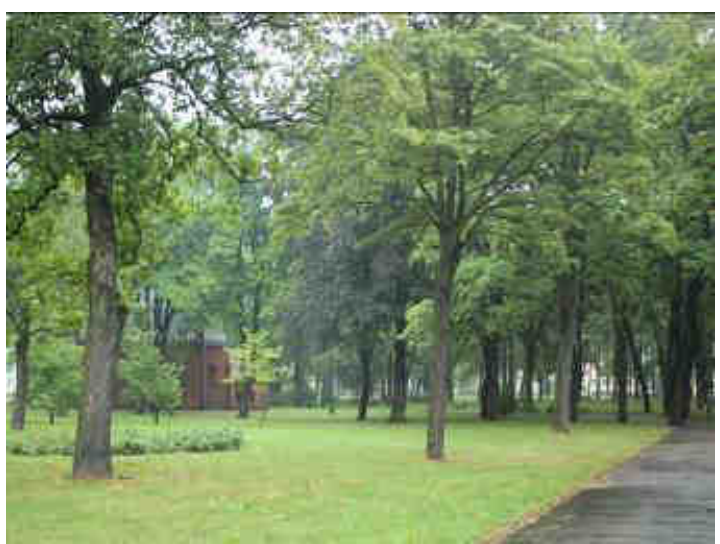

Fig. 7. Park im. Gustawa Manitiusa 
Field studies connected with the inventory of English oaks growing in the analysed parks were conducted in the years 2009-2011 in the summer period (June-August). In the course of the inventory work the following characteristic elements were determined:

1. stem circumference of every tree (measured at a height of $130 \mathrm{~cm}$ above ground level) and in case of multi-stem trees, with trunk division below the height of $130 \mathrm{~cm}$, each stem was measured individually;

2. crown diameter of each tree (in case of trees with an irregular crown two extreme diameters were measured and a mean of the two was calculated);

3. height of each tree;

4. health condition of analysed trees - health condition was evaluated on the basis of criteria for tree health condition by Kosmala et al [22], taking into consideration the health condition of the crown, stem and roots.

Statistical analyses and models were created based on discriminatory analysis. The analyses verified which variables may influence the health condition of English oak (Quercus robur L.) in Poznan parks. The canonical variate analysis (CVA), a canonical version of Fisher's linear discriminatory analysis (LDA), was applied in the construction of the models.

The discriminatory analysis compared the effect of different variables on health condition of specimens in the analysed parks. Parameters investigated in the analysis included distance of parks from the city centre, vicinity of industrial areas, traffic arteries, watercourses and water reservoirs as well as the incorporation of the parks in the system of urban green, emission of gasses from combustion of fossil fuels by households neighbouring with the parks and original land use of the areas in which the analysed parks were established.

In order to state which variables to the greatest degree determine health condition of oaks in the parks of Poznan the following step analysis was applied. All the variables were evaluated and next these variables were included in the model, which contributed the most to the discrimination of groups based on values of $\mathrm{p}$ and $\mathrm{F}$ for the analysed variable. This process was repeated to the moment, when the value of $\mathrm{p}$ decreased below 0.05 for the analysed variable.

In order to determine the boundary level of significance the permutation Monte Carlo test was performed (separately for each variable and next for the whole model). All the lists, calculations and graphic elements were performed in the Canoco for Windows software package and in the Microsoft Excel spreadsheet. The following tools of Canoco for Windows were used: Canoco for Windows 4.5, CanoDraw for Windows and WCanoIMP.

\section{Results and discussion}

The greatest individuals were found in Park Gorczynski and in Park im. Gustawa Manitiusa, ie 291(27)(27), 304(23)(26) (Table 1). Markedly the greatest circumferences were recorded for oaks growing in Park im. Gustawa Manitiusa (circumference of $207.07 \mathrm{~cm}$ ), which may indicate that they are the oldest specimens among the analysed trees. The greatest mean crown projection area was recorded in Park Gorczynski (18.63 m) and tree height - in Park Tysiaclecia (20.62 m), although the mean differed from the value recorded in the park between Os. Czecha and Os. Rusa and Park im. Gustawa Manitiusa. 
Minimum, maximum and mean values, and standard deviation for analysed parameters

Table 1 of English oaks in Poznan parks

\begin{tabular}{|c|c|c|c|c|c|c|c|c|c|c|c|}
\hline & & $\begin{array}{c}\mathbf{O} \\
{[\mathbf{c m}]}\end{array}$ & $\begin{array}{c}\mathbf{D} \\
{[\mathrm{m}]}\end{array}$ & $\begin{array}{c}\mathbf{H} \\
{[\mathbf{m}]}\end{array}$ & $\mathbf{Q}$ & & & $\begin{array}{c}\mathbf{O} \\
{[\mathrm{cm}]}\end{array}$ & $\begin{array}{c}\mathbf{D} \\
{[\mathbf{m}]}\end{array}$ & $\begin{array}{c}\mathbf{H} \\
{[\mathrm{m}]}\end{array}$ & $\mathbf{Q}$ \\
\hline \multirow{4}{*}{ 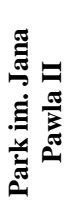 } & MIN & 13 & 1.7 & 2.5 & 1 & \multirow{4}{*}{ 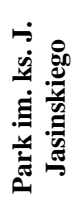 } & MIN & 26 & 7 & 3 & 1 \\
\hline & MAX & 260 & 18 & 17 & 5 & & MAX & 240 & 25 & 29 & 2 \\
\hline & $\bar{x}$ & 80.31 & 6.57 & 10.46 & 1.79 & & $\bar{x}$ & 121.59 & 15.79 & 11.90 & 1.28 \\
\hline & SD & 49.44 & 3.37 & 4.15 & 0.81 & & SD & 68.88 & 5.37 & 6.33 & 0.45 \\
\hline \multirow{4}{*}{ 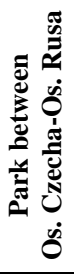 } & MIN & 78 & 6.3 & 8 & 1 & \multirow{4}{*}{ 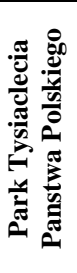 } & MIN & 33 & 4 & 4 & 1 \\
\hline & MAX & 275 & 17.6 & 33 & 2 & & MAX & 243 & 12.5 & 32 & 4 \\
\hline & $\bar{x}$ & 143.07 & 11.54 & 19.21 & 1.64 & & $\bar{x}$ & 137.95 & 8.35 & 20.62 & 1.52 \\
\hline & SD & 53.05 & 2.95 & 7.17 & 0.50 & & SD & 62.78 & 2.69 & 7.75 & 0.74 \\
\hline \multirow{4}{*}{ 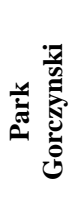 } & MIN & 28 & 7 & 2 & 1 & \multirow{4}{*}{ 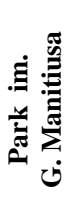 } & MIN & 16 & 0 & 2 & 1 \\
\hline & MAX & 291 & 27 & 27 & 3 & & MAX & 304 & 23 & 26 & 5 \\
\hline & $\bar{x}$ & 129.11 & 18.3 & 12.42 & 1.32 & & $\bar{x}$ & 207.07 & 13.80 & 19.86 & 1.74 \\
\hline & SD & 58.15 & 5.06 & 5.81 & 0.58 & & SD & 53.48 & 4.46 & 2.81 & 0.86 \\
\hline
\end{tabular}

$\mathrm{O}$ - stem circumference, D - crown diameter, H - tree height, Q - health condition

The model presented below presents dependencies between health condition of oaks located in the Poznan parks and their distance from the city centre, vicinity of industrial areas, traffic arteries as well as watercourses and water reservoirs. The best health condition was observed for the individuals located at a distance of $4000-4500 \mathrm{~m}$ from the city centre, as can be seen in Figure 8 (location of point 4000-4500 in relation to vector I). Trees with the worst health class were positively correlated with two variables (K2 and 2000-3000), which may indicate that the health condition of trees in the city is significantly influenced by the vicinity of large traffic arteries as well as the vicinity of the city centre (a radius of 2000-3000 m). Specimens located in parks close to the city centre (2000-3000 m) and surrounded on two sides with large traffic arteries were characterized by the worst health condition.

The model presented below (Fig. 9) presents dependencies between health condition of oaks located in the Poznan parks and age of the trees. The healthiest specimens were observed in the age range of 61-70 years old. This may indicate that English oaks at this stage of development are resistant to habitat conditions and some pathogens. Trees with the worst health class were positively correlated with one variable (the age range of 81-90 years old), which indicates that English oaks may be the most sensitive to the external condition at that age. Specimens at the age of 101-110 and more than 121 years old were characterized by the health condition class III. 


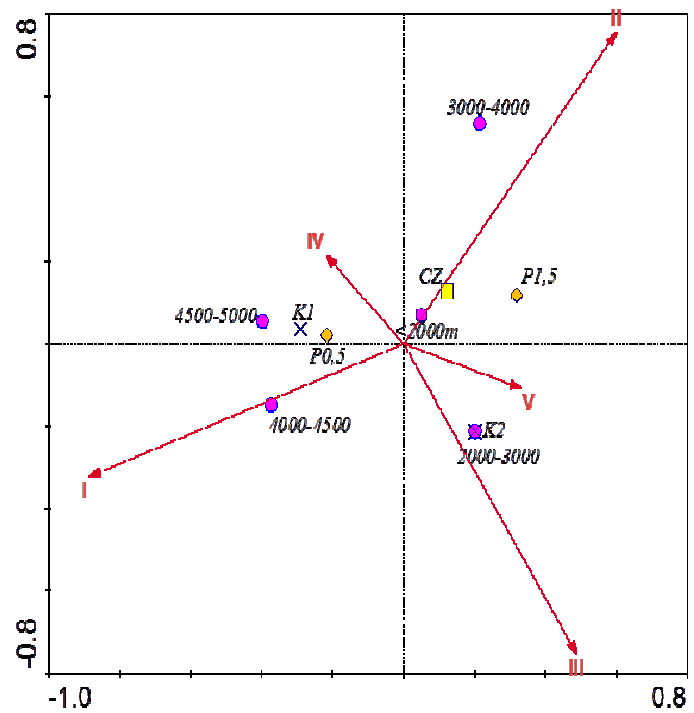

Fig. 8. The CVA model $(n=203)$ - dependencies between health condition of oaks in the Poznan parks and location of parks, vicinity of industrial areas, traffic arteries as well as watercourses and water reservoirs [2000-3000 - distance of park from the city centre; K1, K2 - vicinity of one (two) traffic arteries; P0.5; P1.5 - vicinity of industrial areas at $<0.5$ and $<1.5 \mathrm{~km}$; vicinity of watercourses and water reservoirs] $(p<0.05)$

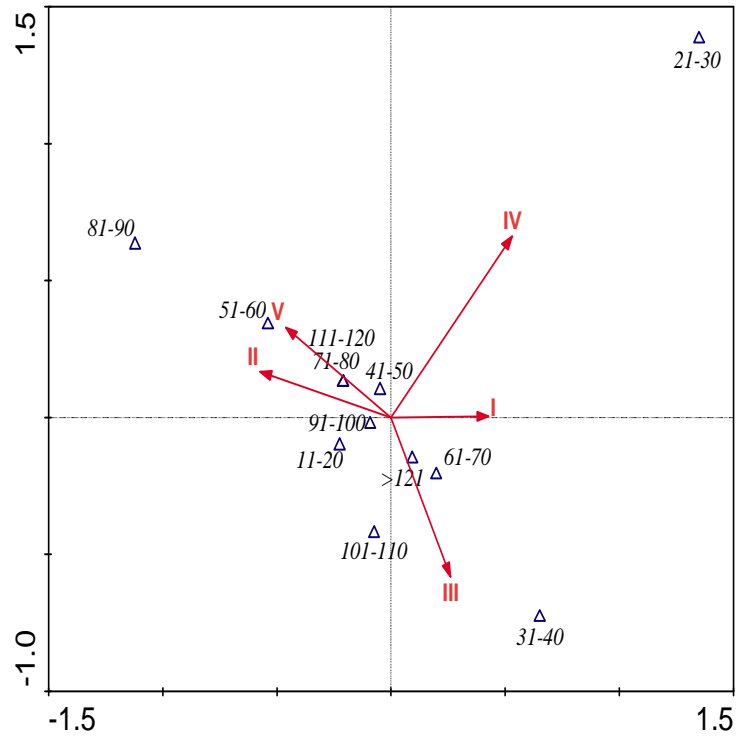

Fig. 9. The CVA model $(n=203)$ - dependencies between health condition of oaks in the Poznan parks and the age of analysed trees [according to the age ranges] $(p<0.05)$ 


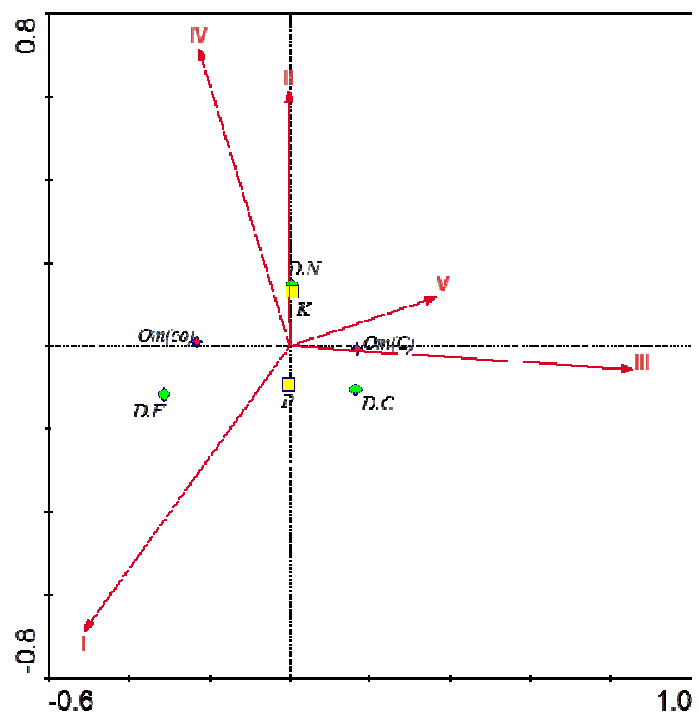

Fig. 10. The CVA model $(n=203)$ - dependencies between health condition of oaks in the Poznan parks and original land use of areas in which parks were established, heating methods of houses located in areas adjacent to parks and incorporation into the system of the city green [D.N. former wasteland, D.C. - former cemeteries, D.F. - former forts; Om(co) - housing districts with central heating system, $\mathrm{Om}(\mathrm{C})$ - housing districts heated using fossil fuels; $\mathrm{K}$ - parks incorporated into green wedges, $\mathrm{P}$ - parks incorporated into green rings] $(p<0.05)$

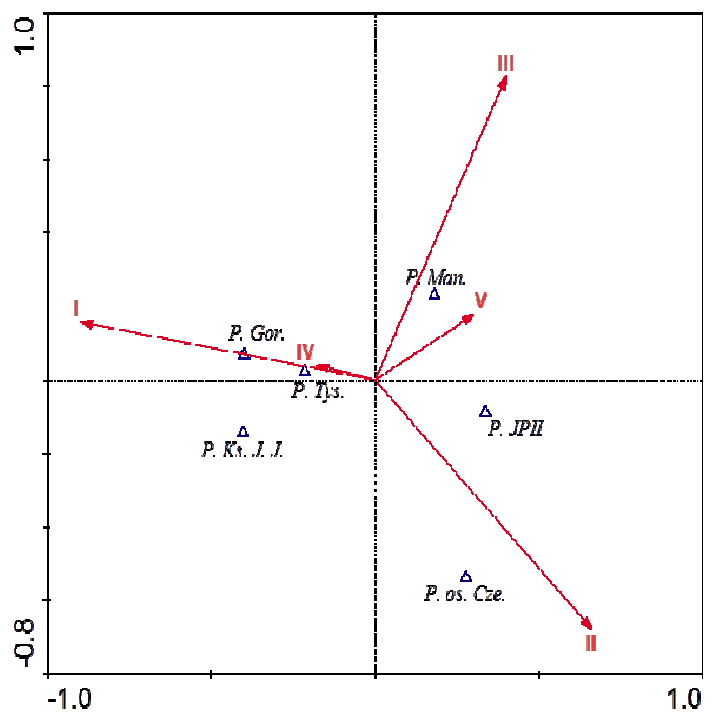

Fig. 11. The CVA model CVA $(n=203)$ - dependencies between health condition of oaks in Poznan parks and analysed parks [P. Gor. - Park Gorczynski, P. Tys. - Park Tysiaclecia Panstwa Polskiego, P. Ks. J. J. - Park im. ks. Jozefa Jasinskiego, P. Man. - Park im. Gustawa Manitiusa, P. JPII - Park im. Jana Pawla II, P. os. Cze. - Park between Os. Czecha and Os. Rusa] $(p<0.05)$ 
Health condition of oaks in the Poznan parks was also significantly influenced by the original land use of the areas, in which the parks were established. The best health condition was observed for trees growing in the areas of former forts, as indicated in Figure 10 (most specimens had health condition class I). Dependencies (stimulants) were also shown between the heating method used in houses located in the adjacent areas and trees being assigned to health condition classes III and IV. Housing districts heated using fossil fuels, mainly coal, could have a negative effect on health condition of English oak (Quercus robur L.) in the Poznan parks. No significant correlation was found in the form of a stimulant or destimulant between health condition of oaks and location in the wedge-ring system of the Poznan urban green.

The model in Figure 11 presents dependencies between health condition of individual trees in the parks and the distribution of this parameter in a specific area (park). The best health condition was observed in Park Gorczynski and Park im. ks. Jozefa Jasinskiego, where trees in class I predominated. In turn, the worst health condition of oaks was recorded in two parks, Park im. Gustawa Manitiusa and Park im. Jana Pawla II. Probably the distribution of health condition in the parks was influenced by the location of the parks in Poznan.

\section{Conclusions}

1. The best health condition was recorded for specimens of English oak (Quercus robur L.) in Park Gorczynski and Park im. ks. J. Jasinskiego, while the worst health condition was found for those growing in Park im. G. Manitiusa.

2. The worst health condition was found for English oaks growing in parks located within a 2-3 $\mathrm{km}$ radius from the city centre.

3. Health condition of oaks growing in public parks in Poznan was influenced by the vicinity of traffic arteries. Trees of the analysed species growing in the parks having two common boundaries with traffic arteries were characterised by a worse health condition than English oaks in the other parks.

4. Trees of the analysed species, growing in parks located in districts heated using fossil fuels had a markedly worse health condition than oaks growing in parks in housing districts with the central heating system. This indirectly indicates an adverse effect of air pollution with $\mathrm{SO}_{\mathrm{X}}$ and $\mathrm{NO}_{\mathrm{X}}$ on health condition of English oak (Quercus robur L.) in Poznan.

\section{Acknowledgments}

This work was financially supported by grant No. 507.655.35.

\section{References}

[1] Boratyński A, Boratyńska K, Filipiak M. Morfologia, systematyka i geograficzne rozmieszczenie. Systematyka i rozmieszczenie [Morphology, systematics and geographical distribution. Systematics and distribution]. In: Nasze drzewa leśne. Monografie popularnonaukowe [Our forest trees. Popular science monographs]. Vol. 11. Dęby [Oaks]. Poznań - Kórnik: Polska Akademia Nauk. Instytut Dendrologii; 2006.

[2] Lyr H. Effect of the root temperature on growth parameters of various European tree species. Ann Sci For. 1996;53:317-323.

[3] Thomas FM, Sporns K. Frost sensitivity of Fagus sylvatica and co-occurring deciduous tree species at exposed sites. Flora. 2009;204:74-81. DOI: 10.1016/j.flora.2008.01.006. 
[4] Zajączkowski J, Brzeziecki B, Perzanowski K, Kozak I. Wpływ potencjalnych zmian klimatycznych na zdolność konkurencyjną głównych gatunków drzew w Polsce [Impact of potential climate chan ges on competitve ability of main forest tree species in Poland]. SYLWAN. 2013;157(4):253-261.

[5] Vesterdal L, Elberling B, Christiansen JR, Callesen I, Schmidt IK. Soil respiration and rates of soil carbon turnover differ among six common European tree species. Forest Ecol Manage. 2012;264:185-196. DOI: 10.1016/j.foreco.2011.10.009.

[6] Werf van der GW, Sass-Klassen UGW, Mohren GMJ. The impact of the 2003 summer drought in the intra-annual growth pattern of beech (Fagus sylvatica L.) and oak (Quercus robur L.) on a dry site in the Netherlands. Dendrochronologia. 2007;25:103-112. DOI: 10.1016/j.dendro.2007.03.004

[7] Kramer K, Vreugdenhil SJ, van der Werf DC. Effects of flooding on teh recruitment, damage and mortality of riparian tree species: Afield and simulation study on the Rhine floodplain. Forest Ecology and Managment. 2008;255:3893-3903. DOI: 10.1016/j.foreco.2008.03.044.

[8] Sonesson K. Oak decline in southern Sweden. Scand J For Res. 1999;14:368-375.

[9] Eichhorn J, Paar U. Oak decline in Europe. Methods and results of assessments in the ICP forests. In: Oszako T, Delatour C, editors. Recent Advances on Oak Health in Europe. Warszawa: IBL; 2000:41-52.

[10] Bugała W. Dęby w zadrzewieniach [Oaks in tree plantings]. In: Nasze drzewa leśne. Monografie popularnonaukowe [Our forest trees. Popular science monographs]. Vol. 11. Dęby [Oaks]. Poznań - Kórnik: Polska Akademia Nauk. Instytut Dendrologii; 2006.

[11] Bittner S, Talkner U, Krämer I, Beese F, Hölscher D, Priesack E. Modeling stand water budgets of mixed temporate broad-leaved forest stands by considering variations in species specific drought response. Agricultural and Forest Meteorol. 2010;150:1347-1357. DOI: 10.1016/j.agrformet.2010.06.006.

[12] Saha S, Kuehne C, Kohnle U, Brang P, Ehring A, Geisel J, et al. Growth and quality of young oaks (Quercus robur and Quercus petraea) grown in cluster planting in central Europe: A weighted meta-analysis. Forest Ecol Manage. 2012;283:106-118. DOI: 10.1016/j.foreco.2012.07.021.

[13] Karolewski P. Ochrona [Protection]. In: Nasze drzewa leśne. Monografie popularnonaukowe [Our forest trees. Popular science monographs]. Vol. 11. Dęby [Oaks]. Poznań - Kórnik: Polska Akademia Nauk. Instytut Dendrologii; 2006.

[14] Kardel F, Wuyts K, Babanezhad M, Wuytack T, Adriaenssens S, Samson R. Tree leaf wettability as passive bio-indicator of urban habitat quality. Environ Exp Botan. 2012;75:277-285. DOI: 10.1016/j.envexpbot.2011.07.011

[15] Lerario P, Luisi N, Giglio de A, Giolia de T. Chemical characteristics of rain water in Apulia and effect of simulated acid rain on oak and pine. In: Lorenzini G, Soldatini GF, editors. Responses of plants to air pollution: biological and economic aspects. Proceedings of a conference held in Pisa, Italy, 7-8 April 1994. Agricoltura Mediterranea Special Volume. Pacini Editore. Ospedaletto Pisa, Italy;1995:372-379.

[16] Brischke C, Behnen CJ, Lenz MT, Brandt K, Melcher E. Durability of oak timber bridges - Impact of inherent wood resistance and environmental conditions. Int Biodeterioration \& Biodegradat. 2012;75:115-123. DOI: 10.1016/j. ibiod.2012.09.010.

[17] Anjos C, Magalhães F, Clara M, Abreu MM. Metal (Al, Mn, Pb and Zn) soils extractable reagents for available traction essessment: Comparison using plant, and dry and moist soils from the Braçal abandoned lead mine area, Portugal. J Geochem Explorat. 2012;113:45-55. DOI: 10.1016/j.gexplo.2011.07.004.

[18] Gerosa G, Marzuoli R, Desotgiu R, Bussotti F, Ballarin-Denti A. Visible leaf injury in young trees of Fagus sylvatica $\mathrm{L}$. and Quercus robur $\mathrm{L}$. in relation to ozone uptake and ozone exposure. An open-top chambers experiment in South Alpine environmental condition. Environ Pollut. 2008;152:274-284. DOI: 10.1016/j.envpol.2007.06.045.

[19] Pyttel PL, Fischer UF, Suchomel C, Gärtner SM, Bauhus J. The effect of harvesting on stomp mortality and re-sprouting in aged oak coppice forests. Forest Ecol Manage. 2013;289:18-27. DOI: 10.1016/j.foreco.2012.09.046.

[20] Mertens J, Van Nevel L, De Schrijver A, Piesschaert F, Oosterbaan A, Tack FMG, et al. Tree species effect on the redistribution of soil metals. Environ Pollut. 2007;149:173-181. DOI: 10.1016/j.envpol.2007.01.002.

[21] Meyer L, Brischke C, Melcher E, Brandt K, Lenz MT, Soetbeer A. Durability of English oak (Quercus robur L.) - Comparison of decay progress and resistance under various laboratory and field conditions. Int Biodeterioration \& Biodegradat. 2014;86:79-85. DOI: 10.1016/j. ibiod.2013.06.025.

[22] Kosmala M, Rosłon-Szeryńska E, Suchocka M. Metoda oceny kondycji drzew z uwzględnieniem bezpieczeństwa i uszkodzeń mechanicznych [Methods of evaluating tree vigour in terms of safety and mechanical damage]. Warszawa: Instytut Gospodarki Przestrzennej i Mieszkalnictwa; 2009. 


\title{
OCENA WPŁYWU ZMIENNYCH ŚRODOWISKOWYCH NA STAN ZDROWOTNY Quercus robur L. W PARKACH
}

\author{
Katedra Terenów Zieleni i Architektury Krajobrazu, Uniwersytet Przyrodniczy w Poznaniu
}

\begin{abstract}
Abstrakt: Badania dotyczyły wpływu różnych zmiennych środowiskowych na stan zdrowotny dębu szypułkowego (Quercus robur L.). Wykazano, że na terenie parków publicznych Poznania stan zdrowotny omawianego gatunku jest dobry. Stwierdzono, że wpływ na stan zdrowotny tego gatunku w parkach Poznania mają: oddalenie od ścisłego centrum miasta, bliskość arterii komunikacyjnych oraz emisja gazów ze spalania paliw kopalnych przez sąsiadujące z parkami gospodarstwa domowe. Mimo że wyniki uzyskane w pracy potwierdzają dane literaturowe dotyczące wpływu zmiennych środowiskowych na stan zdrowotny dębu szypułkowego (Quercus robur L.), to wykazano, że niektóre zmienne środowiskowe mają większy wpływ na stan zdrowotny badanego gatunku w Poznaniu.
\end{abstract}

Słowa kluczowe: dąb szypułkowy (Quercus robur L.), stan zdrowotny, Poznań, zmienne środowiskowe, modele statystyczne 